\title{
KONDISI DAN STATUS KEBERLANJUTAN EKOSISTEM TERUMBU KARANG DI KAWASAN KONSERVASI PERAIRAN PULO PASI GUSUNG, SELAYAR
}

\section{CORAL REEF ECOSYSTEM'S ASSESSMENT AND SUSTAINABILITY IN MARINE CONSERVATION AREA PULO PASI GUSUNG, SELAYAR}

\author{
Waode Siti Cahyani ${ }^{1 *}$, Isdradjad Setyobudiandi ${ }^{2}$, dan Ridwan Affandy ${ }^{2}$ \\ ${ }^{1}$ Program Studi Pengelolaan Sumberdaya Pesisir dan Lautan, FPIK-IPB, Bogor \\ ${ }^{2}$ Departemen Manajemen Sumberdaya Perairan, FPIK-IPB, Bogor \\ *E-mail: cahyaodhe@yahoo.co.id
}

\begin{abstract}
Coral reefs are one of the important ecosystems in coastal areas. Coral reefs have important values for coastal communities and their presence is particularly vulnerable to disturbance from both natural and anthropogenic activities. Establishment of a marine conservation area is essential to protect coral reefs from over-exploitation. This study aims to assess the condition of coral cover and sustainability status of coral reef ecosystem in Pulo Pasi Gusung Marine Conservation Area (KKPD) of Selayar. The results of this study are expected to provide recommendation for government in policy making related to better management to improve supervision of coral reef ecosystems in Pulo Pasi Gusung KKPD. Data collection was conducted using line intercept transect (LIT) at 3 and 10 meter depth. Coral reef sustainability status was analyzed using Multi Dimensional Scaling (MDS) with Rap Insus COREMAG (Rapid Appraisal-Index Sustainability of Coral Reef Management) by comparing the management before the establishment of KKPD (Year 2010) and after the establishment of KKPD (Year 2015). Assessment is conducted on 5 dimensions namely ecological, economic, social cultural, technological and infrastructure dimensions as well as legal and institutional dimensions. The results of the analysis of the five dimensions in the assessment of coral reef sustainability status in Pulau Pasi after the establishment of KKPD on average experienced an increase in sustainable index than before the establishment of KKPD.
\end{abstract}

Keywords: coral reefs, conservation area, sustainability status, management

\begin{abstract}
ABSTRAK
Terumbu karang merupakan salah satu ekosistem penting di wilayah pesisir. Terumbu karang memiliki nilai penting bagi masyarakat pesisir dan keberadaannya sangat rentan terhadap gangguan baik yang berasal dari alam maupun kegiatan antropogenik. Penetapan suatu perairan menjadi kawasan konservasi sangat penting untuk melindungi terumbu karang dari eksploitasi berlebihan. Penelitian ini bertujuan untuk mengkaji kondisi tutupan karang dan status keberlanjutan ekosistem terumbu karang di Kawasan Konservasi Perairan Daerah (KKPD) Pulo Pasi Gusung, Selayar. Hasil penelitian diharapkan dapat memberikan rekomendasi bagi pemerintah daerah dalam penentuan kebijakan terkait pengelolaan yang lebih baik untuk meningkatkan pengawasan terhadap ekosistem terumbu karang di KKPD Pulo Pasi Gusung. Pengambilan data tutupan karang menggunakan metode line intercept transect (LIT) pada kedalaman 3 meter dan 10 meter. Status keberlanjutan terumbu karang dianalisis menggunakan metode Multi Dimensional Scaling (MDS) dengan tehnik Rap Insus COREMAG (Rapid Appraisal-Index Sustainability of Coral Reef Management) dengan membandingkan pengelolaan sebelum terbentuknya KKPD (Tahun 2010) dan setelah terbentuknya KKPD (Tahun 2015). Penilaian dilakukan terhadap 5 dimensi yaitu dimensi ekologi, ekonomi, sosial budaya, teknologi dan infrastruktur serta dimensi hukum dan kelembagaan. Hasil analisis dari 5 dimensi dalam penilaian status keberlanjutan terumbu karang di Pulau Pasi setelah terbentuknya KKPD rata-rata mengalami peningkatan indeks berkelanjutan dibandingkan sebelum terbentuknya KKPD.
\end{abstract}

Kata kunci: terumbu karang, kawasan konservasi, status keberlanjutan, pengelolaan 


\section{PENDAHULUAN}

Beragam definisi dan kategori Kawasan Konservasi Perairan (KKP) telah dikenal dunia saat ini. Menurut International Union for Conservation of Nature (IUCN, 2004)) Kawasan Konservasi Perairan adalah wilayah perairan yang dibatasi secara geografis dengan jelas, diakui, diabdikan dan dikelola, menurut aspek hukum maupun aspek lain yang efektif, untuk mencapai pelestarian alam jangka panjang, lengkap dengan fungsi-fungsi ekosistem dan nilainilai budaya yang terkait. Menurut Peraturan Menteri Kelautan dan Perikanan Nomor 17 Tahun 2008 KKP adalah kawasan perairan yang dilindungi, dikelola dengan sistem zonasi untuk mewujudkan pengelolaan sumberdaya ikan dan lingkungannya secara berkelanjutan. Konservasi wilayah pesisir dan pulau-pulau kecil adalah upaya perlindungan, pelestarian, dan pemanfaatan wilayah pesisir dan pulau-pulau kecil serta ekosistemnya untuk menjamin keberadaan, ketersediaan, dan kesinambungan sumberdaya pesisir dan pulau-pulau kecil dengan tetap memelihara dan meningkatkan kualitas nilai dan keanekaragamannya. Kawasan konservasi laut merupakan alat yang penting untuk perlindungan dan manajemen perikanan. Kawasan konservasi laut dapat melindungi habitat, struktur, fungsi dan intergritas ekosistem, keragaman, kekayaan, kepadatan spesies (Letser et al., 2009; Angulo et al., 2010; Salm et al., 2010).

KKPD Pulo Pasi Gusung terletak di Pulau Pasi, Kabupaten Kepulauan Selayar. Pada tahun 2011 Pemerintah Kabupaten Kepulauan Selayar menetapkan Pulau Pasi sebagai KKPD dengan mengeluarkan SK Bupati Nomor 466/IX/Tahun 2011 tentang pencadangan Kawasan Konservasi Perairan Daerah Pulo Pasi-Gusung sebagai Taman Wisata Perairan dengan luas 5018 ha. Pencadangan Kawasan Konsevasi Pulo Pasi Gusung bertujuan untuk menunjang kelestarian sumberdaya ikan dan ekosistemnya serta mengelola dan melindungi perairan laut di Pulau Pasi yang memiliki sumberdaya alam dan keanekaragaman yang tinggi, salah satunya adalah ekosistem terumbu karang.

Terumbu karang memiliki nilai sumberdaya yang penting bagi masyarakat Pulau Pasi, namun terumbu karang di pulau ini sangat rentan terhadap gangguan. Penambangan karang, penggunaan bahan peledak, racun sianida dan cara tangkap lainnya yang kurang bersahabat dengan ekosistem terumbu karang, merupakan ancaman umum yang dapat menganggu kondisi lingkungan pesisir dan laut di daerah tersebut (Janwar, 2010). Menurut Selig and Bruno (2010) bahwa kegiatan manusia akhirnya akan mempengaruhi struktur bangunan terumbu karang. Secara ekologis, sosial dan nilai ekonomi terumbu karang mendasari betapa pentingnya konservasi terumbu karang secara internasional. Keberhasilan kawasan konservasi laut dalam mengembalikan populasi ikan juga merupakan dampak secara tidak langsung dari keberadaan terumbu karang.

Terbentuknya kawasan konservasi tidak menjamin keberlangsungan suatu ekosistem tertentu. Demikian pula, berhasilnya suatu daerah menjadi kawasan konservasi tidak secara langsung menjamin kesejahteraan masyarakat setempat yang mata pencahariannya bergantung pada sumberdaya pesisir. Walaupun demikian, pencadangan Pulau Pasi sebagai kawasan konservasi diharapkan tidak hanya memberikan manfaat dari fungsi ekologinya saja dengan mengabaikan sisi ekonomi dan sosial. Oleh karena itu perlu dilakukan analisis untuk mengetahui dampak pencadangan Pulau Pasi sebagai kawasan konservasi terhadap kondisi terumbu karang.

\section{METODE PENELITIAN}

\subsection{Waktu dan Lokasi Penelitian}

Penelitian ini dilakukan pada bulan Februari sampai April 2015, bertempat di Pulau Pasi, Kecamatan Bontoharu, Kabupaten Selayar, Propinsi Sulawesi selatan. 

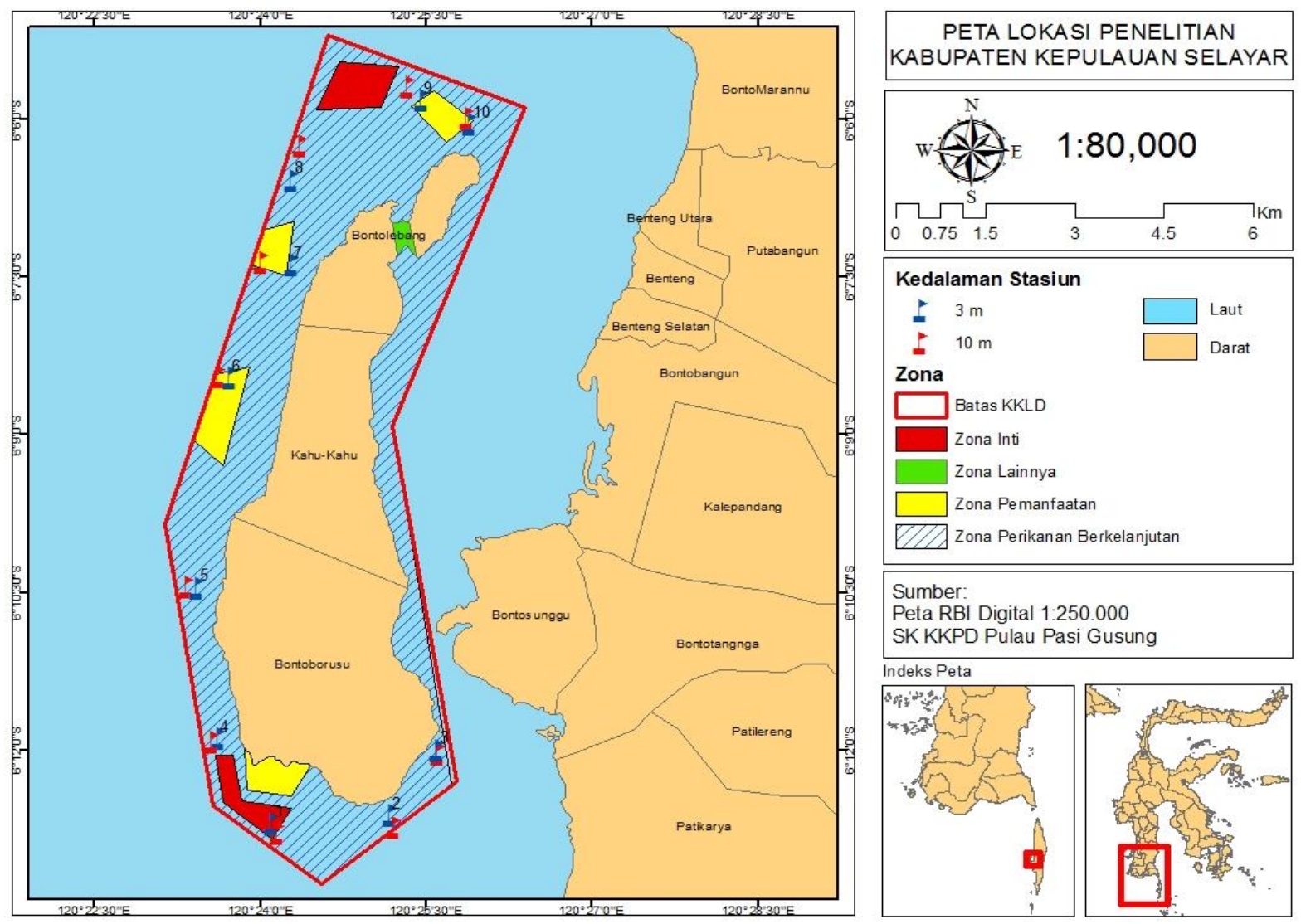

Gambar 1. Lokasi penelitian.

Kawasan konservasi Pulau Pasi Gusung terdapat tiga desa yaitu Desa Bontoborusu, Kahu-Kahu, dan Bontolebang. Lokasi penelitian disajikan pada Gambar 1.

\subsection{Pengambilan Data}

Pengambilan data tutupan karang dilakukan pada 10 titik pengamatan dengan menggunakan metode Line Intercept Transect (LIT). Masing-masing titik pengamatan mewakili kedalaman $3 \mathrm{~m}$ dan 10 m. Panjang transek yang digunakan adalah $50 \mathrm{~m}$ yang direntangkan sejajar garis pantai pada kedalaman $3 \mathrm{~m}$ dan $10 \mathrm{~m}$ dan dilakukan ulangan sebanyak tiga kali.

Informasi yang berhubungan dengan sosial ekonomi dan pengelolaan di kawasan tersebut diperoleh dengan wawancara mendalam dan kuisioner serta dilengkapi dengan data sekunder dari dinas setempat. Pemilihan responden dilakukan secara purposive sampling yaitu teknik pengambilan data yang dilakukan dengan sengaja demi keterwakilan data. Responden merupakan pelaku baik individu ataupun lembaga yang terkait dengan pemanfaatan di pulau ini. Responden berjumlah 100 orang yang terdiri dari: dinas terkait (DKP), kepala desa, pelaku wisata (nelayan pemilik kapal, guide), rumah tangga nelayan, wisatawan, dan tokoh masyarakat.

\subsection{Analisis Data}

\subsubsection{Kondisi Tutupan Karang}

Kriteria penilaian kondisi terumbu karang berdasarkan kategori persentase tutupan karang disajikan pada Tabel 1. Rumus yang digunakan untuk menghitung persentase penutupan karang berdasarkan metode LIT (English et al., 1994) yaitu:

$N i=\frac{l i}{L} \times 10$ 
Keterangan: $\mathrm{Ni}=$ persen penutupan karang, li = panjang total life form I jenis ke $-\mathrm{I}, \mathrm{L}=$ panjang transek ( $\mathrm{n}$ meter).

Tabel 1. Penilaian kondisi terumbu karang (Gomez and Yap, 1998).

\begin{tabular}{cl}
\hline Penutupan $(\%)$ & \multicolumn{1}{c}{ Kriteria } \\
\hline $0-24,9$ & Buruk \\
$25-49,9$ & Sedang \\
$50-74,5$ & Baik \\
$75-100$ & Sangat baik \\
\hline
\end{tabular}

Data luas tutupan karang yang diperoleh secara langsung dibandingkan dengan data sekunder dari penelitian-penelitian sebelumnya untuk melihat perubahan yang terjadi terhadap luas tutupan karang setelah kawasan ini ditetapkan menjadi KKPD.

\subsubsection{Status Keberlanjutan Ekosistem Terumbu Karang}

Analisis keberlanjutan pengelolaan terumbu karang dilakukan dengan metode pendekatan Multi Dimensional Scaling (MDS) dengan teknik Rap-Insus COREMAG (Rapid Appraisal-Index Sustainability of Coral Reef Management) yang telah dimodifikasi dari program RAPFISH (Kavanagh, 2001; Pitcher and Preikshot, 2001; Fauzi dan Anna, 2005).

Penentuan atribut pada penilaian keberlanjutan pengelolaan terumbu karang meliputi dimensi ekologi, ekonomi, sosial budaya, teknologi dan infrastruktur serta hukum dan kelembagaan yang mengacu pada indikator dari Rapfish (Kavanagh, 2001; Pitcher and Preikshot, 2001; Charles, 2000; Nikijuluw, 2002; Arifin, 2008; Adriman et al., 2012) yang telah dimodifikasi. Skor perkiraan setiap dimensi dinyatakan dengan skala terburuk (bad) 0\% sampai yang terbaik (good) 100\%, yang dikelompokkan ke dalam empat kategori yang disajikan pada Tabel 2.

Atribut setiap dimensi dan kriteria baik atau buruk mengikuti konsep Rapfish (Kavanagh, 2001) dan judgement knowladge pakar/stakeholder. Setiap atribut diperkirakan skornya, yaitu skor 3 untuk kondisi baik (good), 0 berarti buruk (bad) dan di antara 03 untuk keadaan di antara baik dan buruk. Skor definitifnya adalah nilai modus, yang dianalisis untuk menentukan titik-titik yang mencerminkan posisi keberlanjutan relatif terhadap titik baik dan buruk dengan teknik ordinasi statistik MDS. Dimensi dan atributatribut yang mempengaruhi status pengelolaan terumbu karang di Pulau Pasi disajikan pada Tabel 2.

Tabel 2. Kategori status keberlanjutan pengelolaan terumbu karang berdasarkan nilai indeks hasil analisis Rap-Insus Coremag.

\begin{tabular}{cl}
\hline Indeks & \multicolumn{1}{c}{ Kategori } \\
\hline$\leq 24,9$ & Buruk \\
$25-49,9$ & Kurang Berkelanjutan \\
$50-74,9$ & Cukup berkelanjutan \\
$>75$ & Baik \\
\hline
\end{tabular}

Hasil ordinasi status keberlanjutan, pada dasarnya memberikan ilustrasi tentang status keberlanjutan setiap dimensi sesuai dengan skor dari atribut-atributnya. Posisi nilai indeks diilustrasikan pada sumbu absis (x) yang mencerminkan status keberlanjutan pengelolaan terumbu karang, sedangkan sumbu ordinat (y) mengindikasikan variasi skor dari atribut-atribut pengelolaan yang telah di telaah (Rembet et al., 2011).

Output dalam bentuk leveraging merupakan output yang memberikan gambaran output apa yang dianggap sensitif untuk mengubah skor keberlanjutan. Leverage diukur dengan standard error melalui root mean square (RMS). Jika RMS menunjukkan skor 3 artinya bahwa atribut tersebut jika dihilangkan akan mengubah skor keberlanjutan sekitar 3\%. Semakin besar nilai RMS semakin besar persentase mengubah skor keberlanjutan. (Fauzi dan Anna, 2005).

Penilaian terhadap analisis keberlanjutan pengelolaan terumbu karang ini akan membandingkan pengelolaan sebelum terbentuknya KKPD (Tahun 2010) dan setelah 
terbentuknya KKPD (Tahun 2015). Analisis ini akan menghasilkan nilai indeks pengelolaan terumbu karang pada dimensi ekologi, ekonomi, sosial budaya, teknologi dan infrastruktur, serta hukum dan kelembagaan. Atribut yang diperoleh merupakan hasil kajian dari berbagai literatur dan hasil pertimbangan ahli.

\section{HASIL DAN PEMBAHASAN}

\subsection{Perubahan Kondisi Tutupan Karang Hidup}

Tujuan utama dibentuknya kawasan perlindungan laut yaitu untuk melindungi ekosistem dari eksploitasi berlebihan yang dapat mengancam keberadaan ekosistem. Kondisi tutupan karang hidup pada tahun 2009 (sebelum pencadangan KKPD), 2010 (proses pencadangan KKPD) dan (2015) pasca pencadangan KKPD bersumber dari hasil penelitian yang dilakukan oleh Ilyas (2009) dan Janwar (2010), dimana metode pengamatan karang yang digunakan adalah LIT, namun yang menjadi koordinat refensi penulis adalah rujukan dari koordinat hasil penelitian Janwar (2010). Perubahan kondisi tutupan karang hidup disajikan pada Gambar 2.

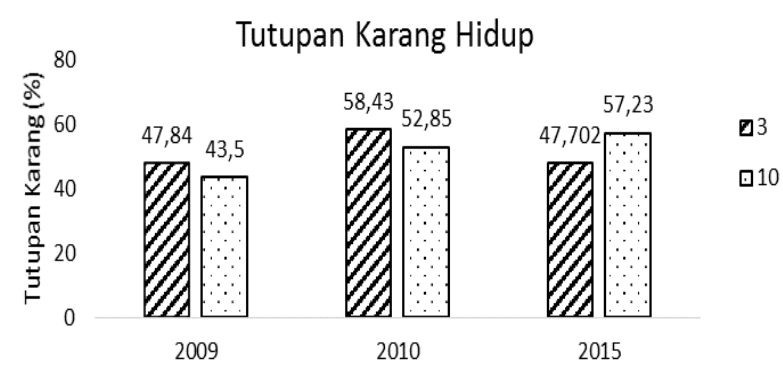

Gambar 2. Kondisi perubahan tutupan karang. Sumber: Ilyas (2009); Janwar (2010); Data primer (2015).

Tutupan karang hidup selalu mengalami fluktuasi dari tahun ke tahun.

Kondisi tutupan karang pada tahun 2010 dan
2015 lebih baik jika dibandingkan kondisi tutupan karang pada tahun 2009 (sebelum pencadangan KKPD). Tutupan karang hidup di tahun 2010 pada kedalaman 3 m yang merupakan tahun pemrosesan pembentukan kawasan konservasi lebih baik jika dibandingkan dengan tahun 2015 (empat tahun setelah pencadangan KKPD). Hal ini dapat disebabkan oleh kondisi alam maupun manusia.

Pemanasan global menyebabkan perubahan suhu secara ekstrim, sehingga terumbu karang sulit beradpatasi merupakan salah satu pemicu banyaknya karang menjadi mati dalam skala global. Dalam skala lokal, penyebab rusaknya terumbu karang terlebih disebabkan oleh pola penangkapan yang bersifat merusak. Penggunaan bom dan bius merupakan contoh kasus yang terjadi di lokasi penelitian. Dalam kasus alat tangkap, penggunaan alat tangkap tradisional seperti bubu juga ternyata menambah peluang semakin terancamnya karang, hal ini terjadi karena ketika bubu diturunkan, harus ada pemberat untuk menahan bubu agar tidak terbawa arus sehingga karang yang menjadi sasaran nelayan, disebabkan untuk membawa batu dari atas sangat menyulitkan penyelam bubu.

Perubahan kondisi lingkungan perairan (suhu, salinitas, kecerahan, dan kecepatan arus) sangat mempengaruhi pertumbuhan terumbu karang. Perbandingan kondisi perairan dari tahun 2009, 2010, dan 2015 disajikan pada Gambar 3.

Kondisi perairan lingkungan pada tahun 2009, 2010, dan 2015 rata-rata yaitu: Suhu $29,6^{\circ} \mathrm{C}, 30,8^{\circ} \mathrm{C}$, dan $29^{\circ} \mathrm{C}$. Salinitas sebesar 32,5 ppt, 31,6 ppt, dan 30,2 ppt. Kecerahan sebesar $100 \%$; 95,5\%, dan $100 \%$. Kecepatan arus sebesar $0,125 \mathrm{~cm} / \mathrm{dtk}, 6,929$ $\mathrm{cm} / \mathrm{dtk}$, dan 0,094 cm/dtk. Kondisi lingkungan perairan pada tahun 2009, 2010, dan 2015 tidak mengalami perubahan yang signifikan, sehingga faktor kondisi perairan bukan penyebab utama perubahan kondisi tutupan karang. 

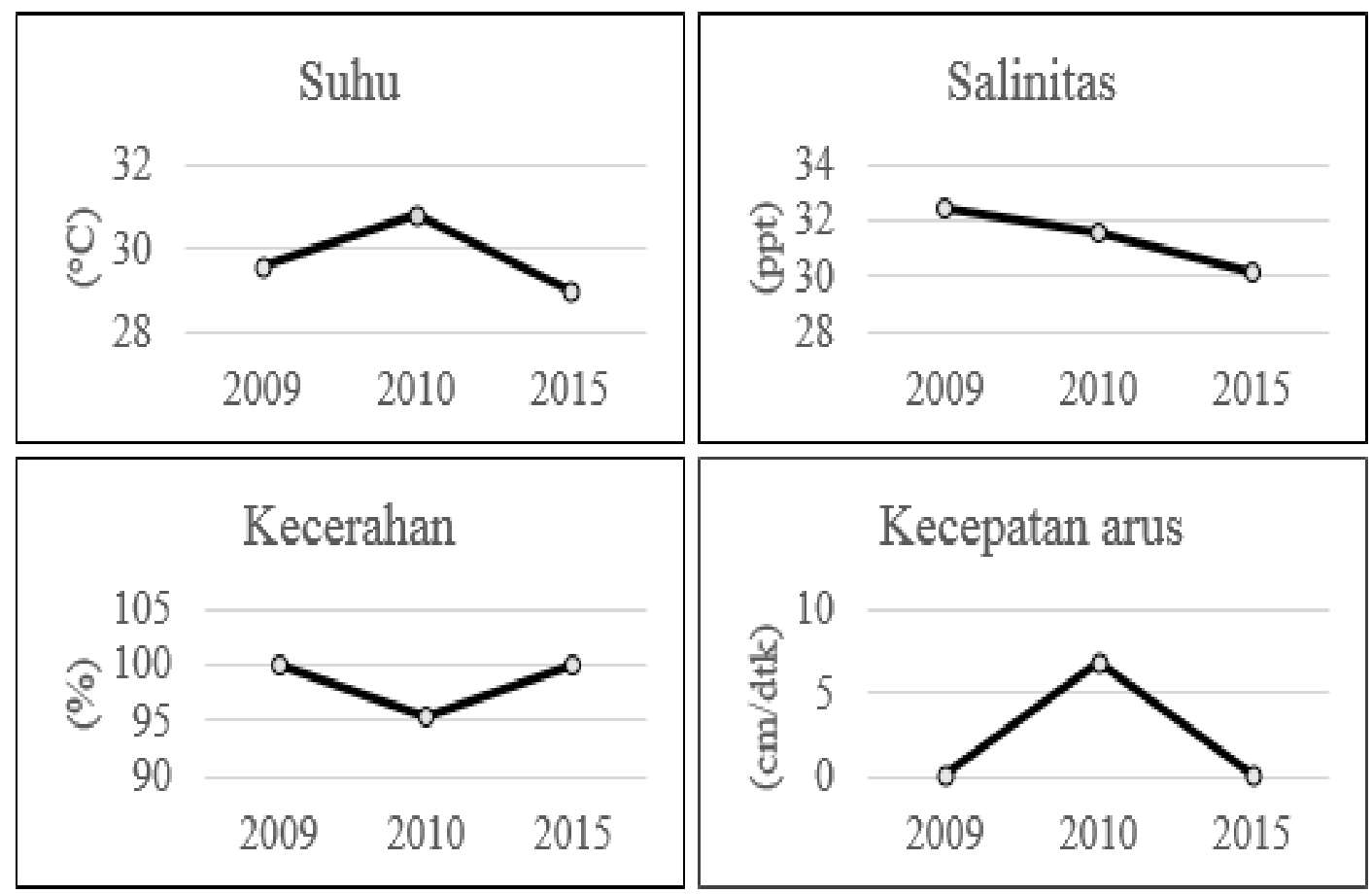

Gambar 3. Grafik lingkungan perairan. Sumber: Ilyas (2009); Janwar (2010); Data primer (2015).

Menurut Kinsman (1964) suhu yang baik untuk pertumbuhan karang berkisar antara $25^{\circ} \mathrm{C}-29^{\circ} \mathrm{C}$, batas minimum $16^{\circ} \mathrm{C}-$ $17^{\circ} \mathrm{C}$ dan batas maksimum sekitar $36^{\circ} \mathrm{C}$. Salinitas yang baik untuk pertumbuhan karang yaitu berkisar 32-35 ppt (Bengen, 2000). Intesitas cahaya merupakan salah satu faktor yang mempengaruhi pertumbuhan karang. Semakin cerah suatu perairan, semakin baik pula pertumbuhan terumbu karang, hal ini berkaitan dengan proses fotosintesis yang dilakukan oleh zooxhantellae, dimana hasil fotosintesis tersebut digunakan sebagai salah satu sumber makanan karang. Arus me rupakan salah satu faktor pendukung pertumbuhan karang. Kecepatan arus yang baik untuk pertumbuhan karang yaitu berkisar 0-0,17 m/det (Nybakken, 1998). Arus berfungsi untuk membawa makanan dan membersih-kan karang dari sedimentasi. Oleh sebab itu, Pertumbuhan karang pada daerah yang berarus cenderung lebih baik daripada perairan yang tenang. Menurut Supriharyono (2007), arus dapat memberikan pengaruh terhadap bentuk pertumbuhan karang. Terdapat kecenderungan bahwa semakin besar tekanan hidrodinamis seperti arus dan gelombang, bentuk karang lebih mengarah ke bentuk pertumbuhan encrusting.

\subsection{Analisis Keberlanjutan Pengelolaan Ekosistem Terumbu Karang \\ 3.2.1. Analisis Ordinasi dan Leverage Dimensi Ekologi}

Berdasarkan hasil analisis ordinasi terhadap atribut-atribut yang mempengaruhi dimensi ekologi, diperoleh nilai keberlanjutan Pulau Pasi pada tahun 2010 sebesar 77,51 dan pada tahun 2015 sebesar 73,26. Indeks keberlanjutan pada tahun 2010 lebih baik dibandingkan tahun 2015. Hal ini disebabkan karena tingginya sedimentasi pada pulau ini. Namun nilai keduanya berada pada indeks > 75 yang menunjukkan bahwa dimensi ekologi di Pulau Pasi termasuk dalam kategori baik.

Hasil analisis leverage ekologi diperoleh tiga atribut yang sensitif yaitu: sedimentasi, keragaman ekosistem, dan 


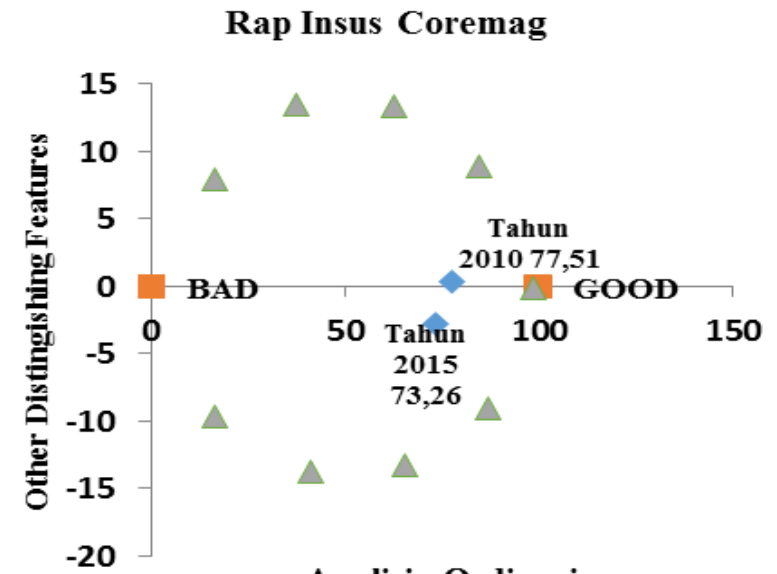

Analisis Ordinasi
Root Mean Square

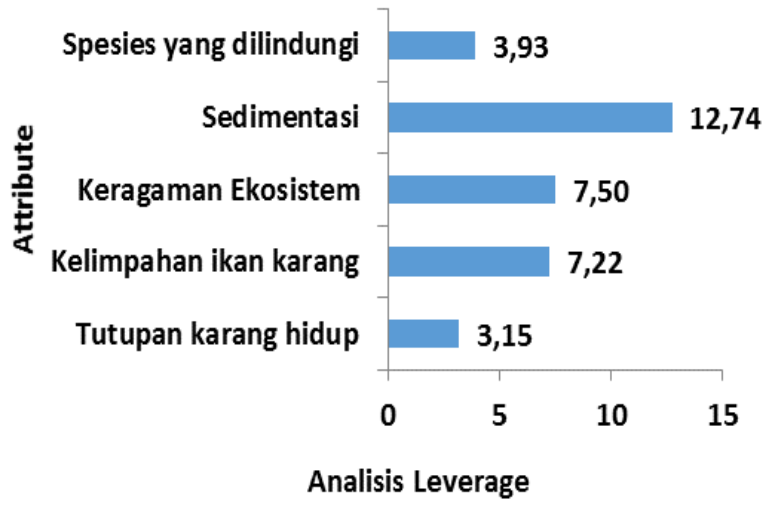

Gambar 4. Analisis ordinasi dan leverage dimensi ekologi.

spesies yang dilindungi. Sedimentasi memiliki nilai RMS yang sangat tinggi yakni sebesar 12,74. Hal ini dapat diartikan bahwa atribut sedimentasi memiliki pengaruh yang paling besar terhadap keberlanjutan pengelolaan ekosistem terumbu karang dari aspek ekologinya. Sedimentasi merupakan salah satu faktor pembatas kehidupan binatang karang. Laju sedimentasi yang cukup tinggi terjadi di perairan pantai Desa Bontoborusu. Analisis ordinasi dan leverage dimensi ekologi disajikan pada Gambar 4. Kerusakan dasar perairan berdampak pada perubahan arus laut sehingga mampu mengangkat lumpur dan serpihan-serpihan pecahan terumbu karang pada suatu tempat. Hal ini tampak pada materi endapan lumpur, berupa tanah, bercampur dengan pasir putih dan serpihan terumbu karang. Menurut informasi masyarakat, dahulu dasar perairan ini berupa pasir putih yang bersih. Kini pemandangan pantai pasir putih tersebut telah berubah dengan dasar perairan pantai berlumpur, airnya keruh dengan sampah yang berserakan (Abdurahhim et al., 2015).

Luas tutupan karang mempengaruhi struktur komunitas lain yang berasosiasi dengan terumbu karang salah satunya yaitu ikan karang. Keragaman ekosistem merupakan salah satu indikator penting dalam kelestarian suatu wilayah. Wilayah yang memiliki keragaman lebih memiliki ketahanan (reseilience) dalam perannya melindungi kawasan pesisir. Keberadaan spesies yang dilindungi pada suatu kawasan merupakan salah satu urgensi dalam pengelolaan kawasan konservasi, sehingga eksistensinya dapat dipertahankan dan terhindar dari kepunahan (Adriman, 2012).

\subsubsection{Analisis Ordinasi dan Leverage Dimensi Ekonomi}

Analisis ordinasi terhadap atributatribut yang mempengaruhi dimensi ekonomi Pulau Pasi pada tahun 2010 sebesar 37,53 dan tahun 2015 sebesar 49,01. Nilai ini termasuk dalam kategori kurang berkelanjutan. Hal ini berarti bahwa pengelolaan sumberdaya terumbu karang dari aspek ekonomi memperlihatkan pembangunan perikanan harus memperhatikan keberlanjutan dan kesejahteraan pelaku perikanan pada tingkat individu.

Berdasarkan hasil analisis leverage terhadap tujuh atribut, diperoleh tiga atribut yang sensitif yang mempengaruhi indeks keberlanjutan terumbu karang dari dimensi ekonomi yaitu ketergantungan pada perikanan sebagai sumber nafkah (RMS 7,83), jumlah objek wisata (RMS 6,45), dan serapan tenaga kerja lokal di sektor pariwisata (RMS 5,35). Analisis ordinasi dan leverage dimensi ekonomi disajikan pada Gambar 5. 
Rap Insus Coremag

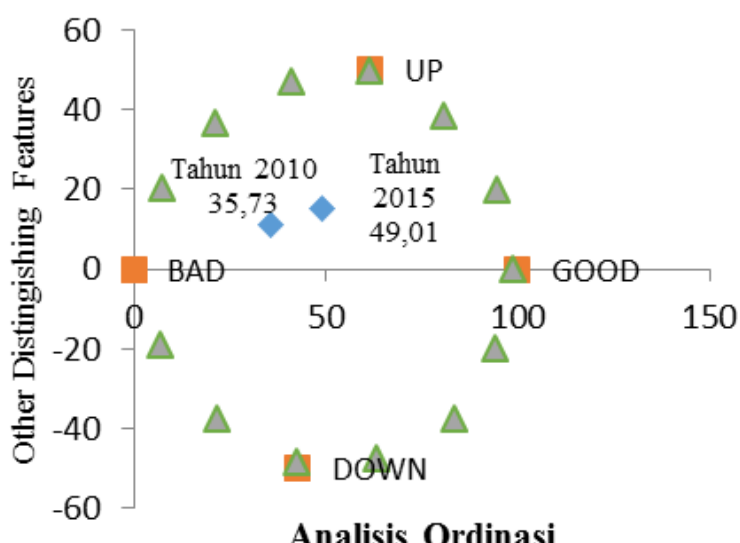

Root Mean Square

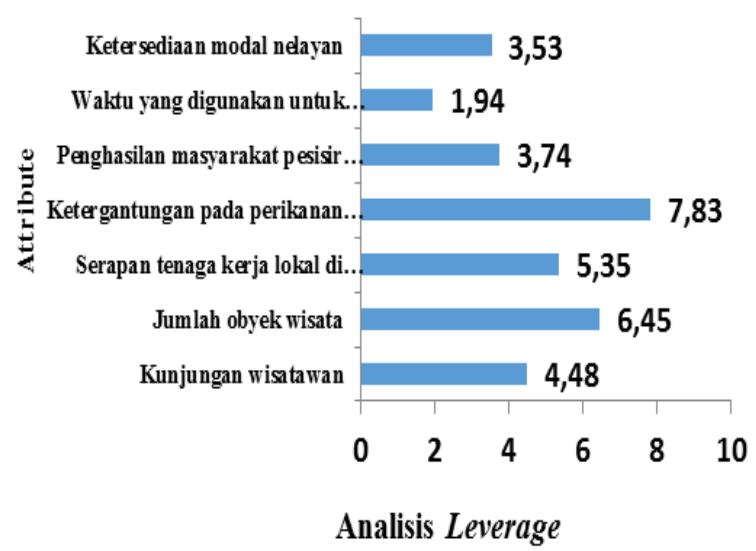

Gambar 5. Analisis ordinasi dan leverage dimensi ekonomi.

Tingginya ketergantungan masyarakat Pulau Pasi pada perikanan sebagai sumber nafkah disebabkan sebagian besar masyarakatnya berprofesi sebagai nelayan. Hal ini juga merupakan penyebab terumbu karang semakin terancam keberlangsungannya karena dieksploitasi secara terus menerus. Berdasarkan hasil wawancara dengan nelayan setempat, jumlah komoditi ikan semakin berkurang. Dahulu nelayan dengan menggunakan perahu tanpa motor dan memancing di daerah pesisir sudah bisa mendapatkan ikan dalam jumlah yang banyak, namun saat ini mereka harus melaut lebih jauh untuk memperoleh ikan itu jumlahnya sangat sedikit.

Pengelolaan kawasan wisata yang tidak optimal menyebabkan serapan tenaga kerja lokal di sektor pariwisata sangat minim. Teknologi alat tangkap ikan sederhana, daya jelajah yang terbatas, dan tingkat eksploitasi yang rendah menyebabkan tingkat pendapatan masyarakat rendah. Rendahnya tingkat pendapatan tidak memungkinkan nelayan melakukan investasi perbaikan teknologi alat tangkap, bahkan memperbaiki dan mempertahankan alat produksi yang ada, nelayan masih kesulitan. Kondisi tersebut, nelayan juga tidak memiliki akses terhadap sumberdaya keuangan yang resmi, seperti perbankan atau koperasi nelayan. Rendahnya tingkat pendapatan, tidak memungkinkan nelayan melakukan investasi jangka panjang seperti pendidikan formal maupun informal yang memungkinkan terjadinya peningkatan kualitas sumberdaya manusia (Abdurrahim et al., 2015).

\subsubsection{Analisis Ordinasi dan Leverage Dimensi Sosial Budaya}

Analisis ordinasi terhadap atributatribut yang mempengaruhi dimensi sosial budaya di Pulau Pasi pada tahun 2010 sebesar 47,07 dan pada tahun 2015 sebesar 56,56. Jika dibandingkan antara tahun 2010 dan 2015, indeks keberlanjutan mengalami peningkatan dari status kurang berkelanjutan 2010 menjadi cukup berkelanjutan 2015. Hal ini berarti dengan terbentuknya KKPD terjadi perubahan yang positif pada dimensi sosial dan budaya.

Hasil analisis leverage terhadap tujuh atribut, diperoleh tiga atribut yang sensitif yang mempengaruhi indeks keberlanjutan terumbu karang dari dimensi sosial budaya yaitu tingkat pendidikan, memiliki nilai estetika, dan pengetahuan lingkungan. Tingkat pendidikan memiliki nilai sensitifitas terbesar yaitu 5,36. Analisis ordinasi dan leverage dimensi sosial budaya disajikan pada Gambar 6. 


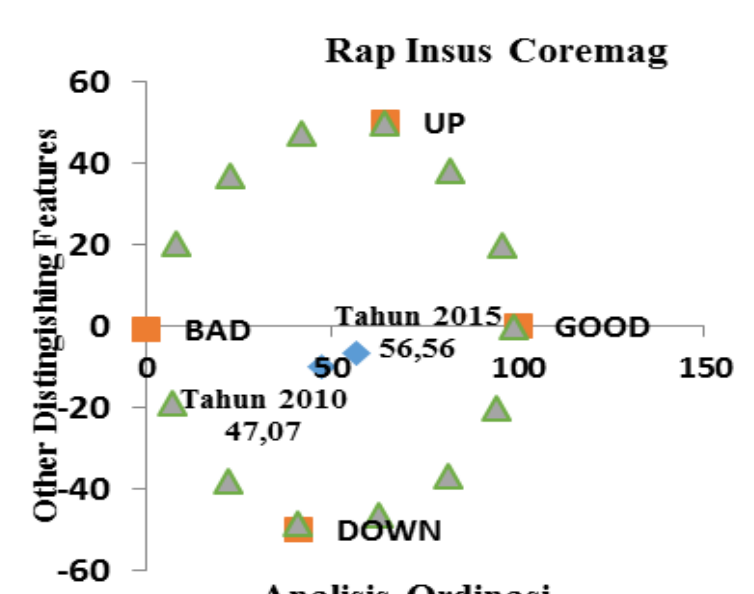

Analisis Ordinasi

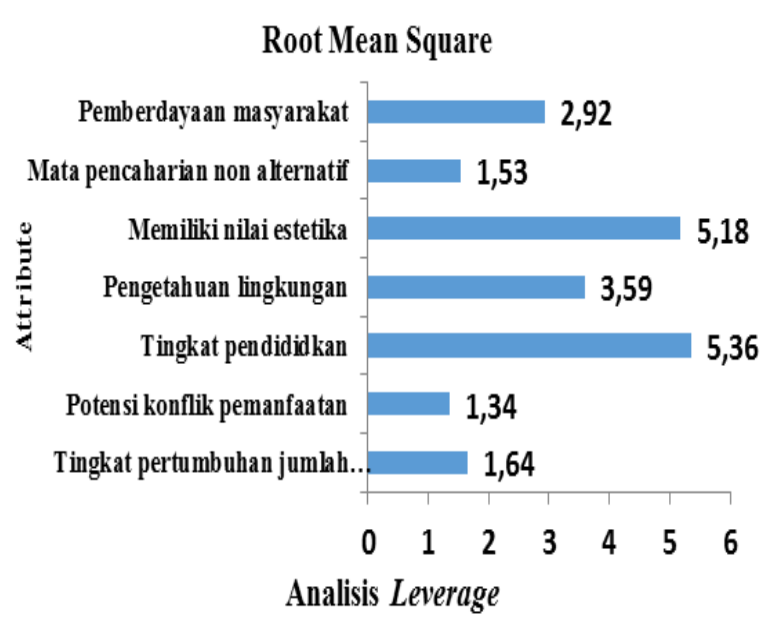

Gambar 6. Analisis ordinasi dan leverage dimensi sosial budaya.

Tingkat pendidikan masyarakat Pulau Pasi secara umum tergolong rendah. Sebagian besar masyarakatnya tidak menamatkan pendidikan setingkat sekolah dasar. Hanya beberapa warga yang memiliki jabatan struktural yang memiliki pendidikan tinggi. Rendahnya tingkat pendidikan turut serta mempengaruhi kurangnya pengetahuan masyarakat terhadap pengetahuan lingkungan. Salah satu upaya yang dapat dilakukan pemerintah yaitu dengan memberikan sosialisasi mengenai pengetahuan lingkungan. Pencadangan ketiga desa dan perairannya sebagai KKPD sejak tahun 2011 juga belum memberikan manfaat bagi penduduk. Menurut penduduk, pemerintah hanya pernah memberikan satu kali sosialisasi saja tanpa pernah mengetahui dan menerima manfaat dengan jelas dari KKPD (Abdurrahim et al., 2015). Program pemberdayaan masyarakat sudah cukup banyak dilakukan pemerintah di Pulau Pasi antara lain: bantuan budidaya ikan kerapu, bantuan modal usaha abon ikan, dan bantuan mesin penggiling tepung terasi. Namun sebagian besar program tersebut tidak berjalan maksimal. Persoalan teknis seperti kesulitan dalam pemasaran, lemahnya disiplin dan tanggung jawab dalam pengelolaan keuangan mikro, dan sulitnya bahan baku. Hal ini disebabkan masih lemahnya studi kelayakan yang dilakukan serta pendampingan tidak berkelanjutan (Abdurrahim et al., 2015).

\subsubsection{Analisis Ordinasi dan Leverage Dimensi Teknologi dan Infrastruktur}

Dimensi teknologi diperlukan secara khusus di daerah dimana pemanfaatan langsung terhadap terumbu karang merupakan bagian yang dominan (Susilo, 2003). Dimensi teknologi mencerminkan seberapa jauh penggunaan teknologi dapat meminimumkan resiko kegagalan keberlanjutan pemanfaatan terumbu karang (Arifin, 2008). Hasil analisis ordinasi terhadap atributatribut yang mempengaruhi dimensi teknologi dan infrastruktur di Pulau Pasi pada tahun 2010 sebesar 40,16 dan pada tahun 2015 sebesar 43,95. Nilai ini termasuk dalam kategori kurang berkelanjutan.

Hasil analisis leverage terhadap tujuh atribut, diperoleh tiga atribut yang sensitif yang mempengaruhi indeks keberlanjutan terumbu karang dari dimensi teknologi dan infrastruktur yaitu: transplantasi karang (RMS 7,55), efek samping alat tangkap terhadap karang $(5,53)$, dan sarana prasarana pengawasan $(4,40)$. Transplantasi karang memiliki nilai RMS tertinggi yang berarti transplantasi karang memiliki pengaruh yang paling besar terhadap keberlanjutan pengelolaan terumbu karang dari aspek teknologi dan infrastuktur. Analisis ordinasi dan leverage dimensi teknologi dan infrastruktur disajikan pada Gambar 7. 


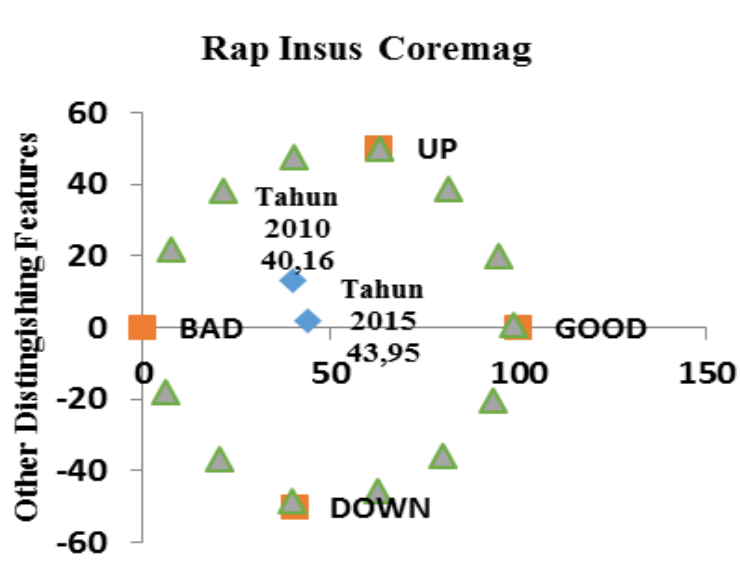

Analisis Ordinasi

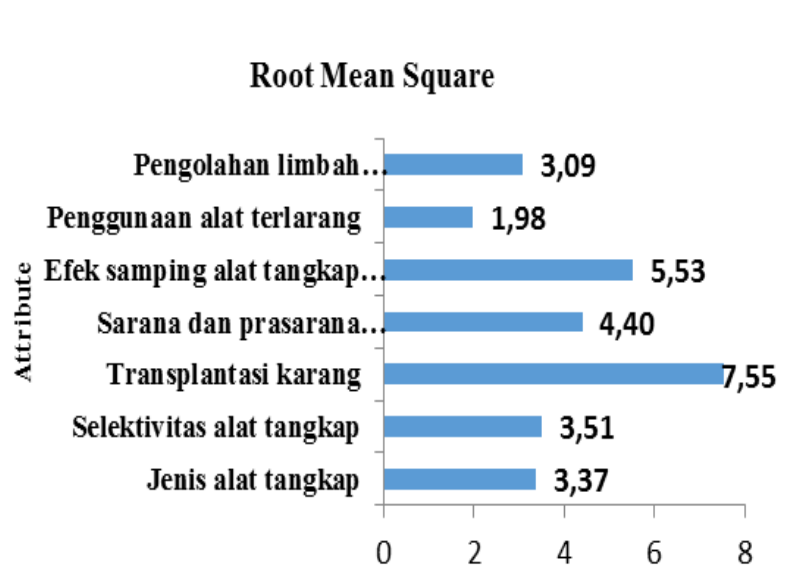

Analisis Leverage

Gambar 7. Analisis ordinasi dan leverage dimensi teknologi dan infrastruktur.

Transplantasi karang merupakan salah satu upaya rehabilitasi untuk pemulihan kembali terumbu karang yang telah rusak. Di stasiun 10 yang merupakan zona inti pernah dilakukan transplantasi karang (Tahun 2011) yang diinisiasi DKP setempat dengan tujuan memberi pemahaman kepada masyarakat pentingnya menjaga terumbu karang. Efek samping alat tangkap terhadap karang sangat mempengaruhi keberlanjutan dari ekosistem terumbu karang itu sendiri. Pada umumnya alat tangkap yang digunakan oleh nelayan setempat antara lain yaitu: pancing, bubu, jaring dan sero. Selain itu, penggunaan bius dan bom marak digunakan di pulau ini sebelum KKPD terbentuk. Setelah KKPD terbentuk penggunaan alat tangkap terlarang ini telah berkurang, karena adanya sanksi dari pemerintah setempat, namun penggunaan bius masih ditemukan di sekitaran pulau karena dilakukan secara diam-diam. Penggunaan alat bantu kompresor dan penggunaan potassium untuk menangkap ikan kerapu dan ikan karang lainnya yang nampak dengan jelas tidak membuat aparat keamanan menegakkan hukumnya dengan tegas. Pembiaran ini membuat para pelaku terus melakukan destructive fishing dan yang pernah tertangkap pun kembali melakukannya. Di sisi lain, pembiaran ini menggoda penduduk desa yang sebelumnya tidak melakukan destructive fishing untuk ikut-ikutan melakukannya (Abdurrahim et al., 2015).
Sarana dan prasarana sebenanya telah ada di KKPD Pulo Pasi Gusung seperti adanya gedung KKPD, perpustakaan, serta pos jaga Coremap, namun semua fasilitas tersebut tidak berfungsi secara maksimal dan gedungnya mulai mengalami kerusakan karena tidak ada pengawasan dari pengelola.

\subsubsection{Analisis Ordinasi dan Leverage Dimensi Teknologi dan Infrastruktur}

Hasil analisis ordinasi terhadap atribut-atribut yang mempengaruhi dimensi hukum dan kelembagaan di Pulau Pasi pada tahun 2010 sebesar 44,52 dan pada tahun 2015 sebesar 51,79. Indeks ini mengalami peningkatan dari kurang berkelanjutan menjadi cukup berkelanjutan.

Hasil analisis leverage terhadap tujuh atribut, diperoleh 3 tiga atribut yang sensitif yang mempengaruhi indeks keberlanjutan terumbu karang dari dimensi hukum dan kelembagaan yaitu pemantauan dan pengawasan, ketersediaan peraturan pengelolaan sumberdaya secara formal, dan tingkat kepatuhan masyarakat. Pemantauan dan pengawasan memiliki nilai RMS sebesar 4,04 , yang berarti bahwa atribut ini sangat mempengaruhi indeks keberlanjutan dari aspek hukum dan kelembagaan. Analisis ordinasi dan leverage dimensi hukum dan kelembagaan disajikan pada Gambar 8 . 

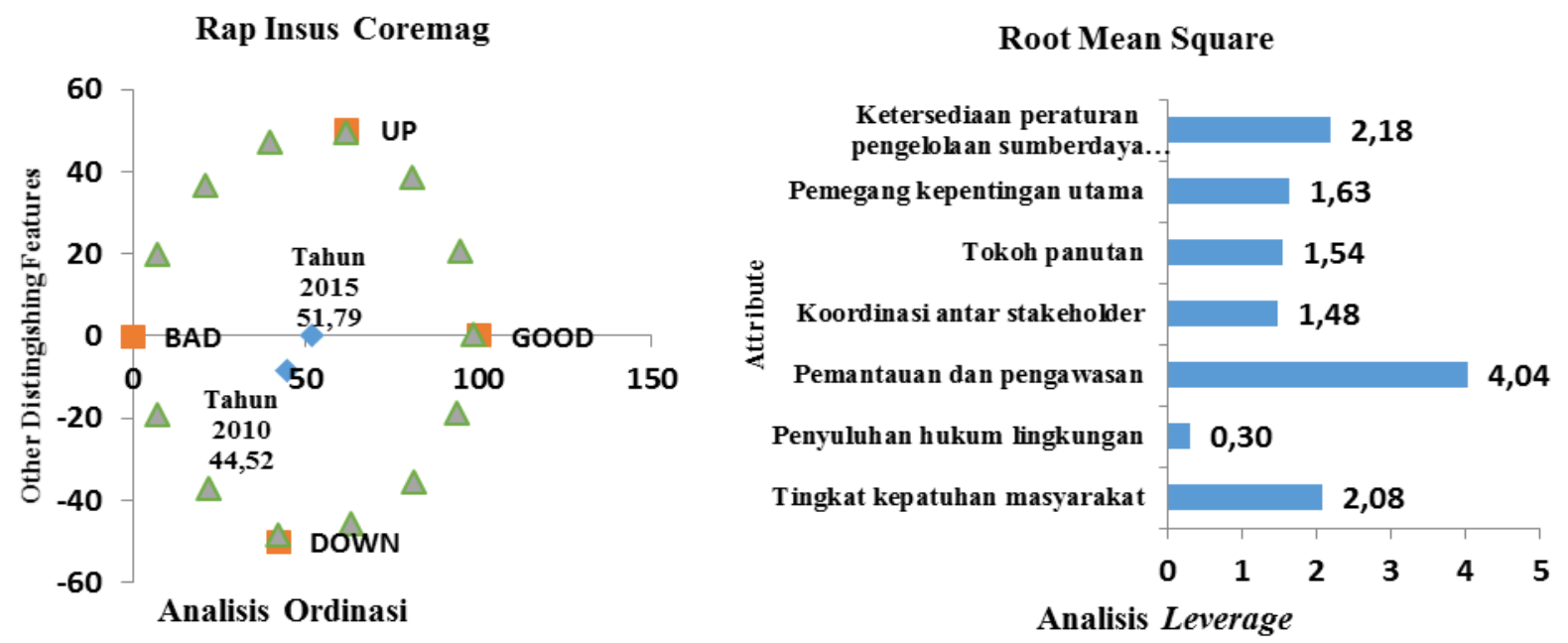

Gambar 8. Analisis ordinasi dan leverage dimensi hukum dan kelembagaan.

Berkaitan dengan masalah kebijakan pengelolaan sumber daya laut, penerapan KKPD telah berdampak pada surutnya partisipasi masyarakat dalam pengawasan wilayah perairan konservasi. Masuknya DPL kedalam kawasan konservasi KKPD memunculkan kesalahpahaman masyarakat seolah-olah kewenangan pengelolaan kawasan perairan DPL telah diambil alih oleh pemerintah daerah. Hal ini disebabkan karena tidak maksimalnya upaya mendorong partisipasi masyarakat dalam pengelolaan sumber daya laut. Tidak adanya tanda batas zona kawasan KKPD serta aturannya, minimnya informasi yang diterima masyarakat, dan tidak ditemukannya papan-papan informasi yang menandai KKPD menambah ketidaktahuan masyarakat (Abdurahhim et al., 2015).

Ketersediaan pengaturan pengelolaan sumberdaya secara formal sebenarnya telah ada semenjak penerbitan SK KKPD, namun implementasi dan sosialisasi kepada warga setempat masih sangat minim dan tidak merata. Hanya sebagian desa saja yang mendapat pemahaman tentang manfaat kawasan konservasi. Pengelolaan yang baik adalah pengelolaan yang menghimpun berbagai kalangan stakeholder untuk mencapai tujuan utama yaitu upaya menjaga kelestarian ekosistem pesisir. Keterlibatan masyarakat lokal untuk turut serta dalam pengelolaan kawasan perlindungan laut sangat diperlukan.
Sebesar apapun upaya pemerintah menjaga lingkungan pesisir tanpa melibatkan masyarakat akan menggangu keseimbangan lingkungan pesisir. Tingkat kepatuhan masyarakat, partispasi, dan komitmen sangat menetukan keberhasilan pembangunan. Pelanggaran peraturan di wilayah pesisir dan laut biasanya didorong oleh persepsi adanya potensi keuntungan yang bisa didapatkan jika nelayan tersebut melanggar (Kuperan, 1997).

\subsubsection{Indeks Keberlanjutan Ekosistem Terumbu Karang}

Kite diagram (diagram layang-layang) menggambarkan status keberlanjutan secara terintegrasi antar berbagai dimensi. Kite diagram ini sering disebut "radar" diagram dimana semakin dekat jarak analisis ke titik nol semakin menunjukkan rendahnya keberlanjutan. Sebaliknya semakin jauh dari titik nol menunjukkan keberlanjutan yang tinggi (Fauzi dan Anna, 2005). Kite diagram keberlanjutan KKPD Pulo Pasi Gusung disajikan pada Gambar 9.

Kite diagram dari ke-lima dimensi keberlanjutan di KKPD Pulo Pasi Gusung (Gambar 9) menunjukkan bahwa terjadi peningkatan pada indeks keberlanjutan semenjak Pulau Pasi ditetapkan sebagai kawasan konservasi. Hal ini terlihat dengan diagram yang semakin menjauhi titik nol. Peningkatan ini menunjukkan bahwa pencadangan Pulau Pasi sebagai KKPD 
memiliki hasil positif untuk keberlanjutan pengelolaan terumbu karang tanpa mengabaikan sisi sosial dan ekonomi masyarakat setempat.

Menguji keakuratan data dalam analisis Rap Insus Coremag dilakukan uji analisis lanjutan yaitu analisis Monte Carlo. Hasil analisis Monte Carlo menunjukan indeks keberlanjutan pengelolaan terumbu karang pada selang kepercayaan $95 \%$ tidak mengalami perbedaan yang signifikan dengan hasil analisis Rap Insus Coremag Kecilnya perbedaan hasil dari kedua analisis tersebut menunjukkan bahwa; (1) kesalahan dalam pembuatan skor dalam atribut relatif kecil, (2) ragam pemberian skor akibat opini relatif kecil, (3) proses analisis yang dilakukan secara berulang relatif stabil, (4) kesalahan dalam pemasukan data dan data yang hilang dapat dihindari (Adriman, 2012). Hasil analisis multidimensi Rap Insus Coremag disajikan pada Tabel 3.

Berdasarkan nilai stress (S) yang diperoleh berdasarkan Tabel 3 menunjukkan hasil analisis yang dilakukan memenuhi standar persyaratan dimana nilai $S<0,25$. Semakin kecil nilai stress yang diperoleh semakin baik model yan dihasilkan, hal ini berbanding terbalik dengan nilai koefisisen determinasi $\left(\mathrm{R}^{2}\right)$ dimana semakin mendekati angka satu maka nilainya semakin baik. Dengan demikian, nilai $\mathrm{S}$ dan $\mathrm{R}^{2}$ dari analisis di atas menunjukkan atribut yang digunakan untuk analisis keberlanjutan pengelolaan keberlanjutan terumbu karang di KKPD Pulo Pasi Gusung memenuhi standar dalam menerangkan ke-lima dimensi pengelolaan yang telah dianalisis.

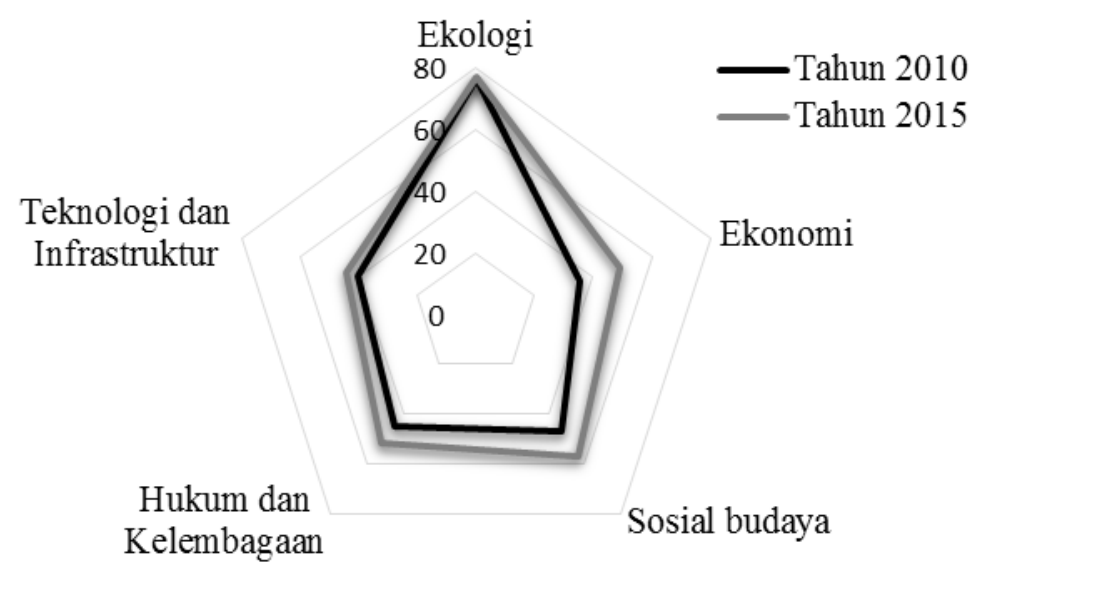

Gambar 9. Kite diagram keberlanjutan KKPD Pulo Pasi Gusung.

Tabel 3. Hasil Analisis Rap Insus Coremag pengelolaan ekosistem terumbu karang di Pulau Pasi.

\begin{tabular}{|c|c|c|c|c|c|c|}
\hline \multirow[t]{2}{*}{ Dimensi } & \multirow[t]{2}{*}{ Stress } & \multirow[t]{2}{*}{$\mathrm{R}^{2}$} & \multicolumn{2}{|c|}{ Indeks Berkelanjutan } & \multicolumn{2}{|c|}{$\begin{array}{c}\text { Analisis Monte } \\
\text { Carlo }\end{array}$} \\
\hline & & & 2010 & 2015 & 2010 & 2015 \\
\hline Ekologi & 0,14 & 0,94 & 77,51 & 73,26 & 74,88 & 71,37 \\
\hline Ekonomi & 0,14 & 0,94 & 37,53 & 49,01 & 36,74 & 49,13 \\
\hline Sosial budaya & 0,15 & 0,94 & 47,07 & 56,56 & 47,26 & 56,19 \\
\hline $\begin{array}{l}\text { Teknologi dan } \\
\text { infrastuktur }\end{array}$ & 0,15 & 0,93 & 40,16 & 43,95 & 41,04 & 44,54 \\
\hline $\begin{array}{l}\text { Hukum dan } \\
\text { kelembagaan }\end{array}$ & 0,17 & 0,93 & 44,52 & 51,79 & 44,71 & 51,80 \\
\hline
\end{tabular}




\section{KESIMPULAN}

Kondisi terumbu karang di Pulau Pasi sebelum dan setelah terbentuknya KKPD pada kedalaman 3 dan 10 meter menunjukkan hasil yang berbeda. Pada kedalaman $3 \mathrm{~m}$ presentase tutupan karang hidup mengalami penurunan, namun pada kedalaman $10 \mathrm{~m}$, persentase tutupan karang hidup cenderung meningkat.

Status keberlanjutan pengelolaan ekosistem terumbu karang setelah pembentukan KKPD Pulo Pasi Gusung pada dimensi ekologi termasuk dalam kategori baik, dimensi ekonomi termasuk kategori kurang berkelanjutan, dimensi sosial budaya ter-masuk kategori cukup berkelanjutan, dimensi teknologi dan infrastruktur termasuk dalam kategori kurang berkelanjutan dan dimensi hukum dan kelembagaan termasuk dalam kategori cukup berkelanjutan.

\section{UCAPAN TERIMA KASIH}

Penulis mengucapkan terima kasih pada Direktorat Jenderal Pendidikan Tinggi (DIKTI) yang memberikan bantuan beasiswa BPPDN selama masa studi 2 tahun.

\section{DAFTAR PUSTAKA}

Abdurrahim, A.Y., A. Wahyono, Sudiyono, dan A.A. Arief. 2015. Data dasar aspek sosial terumbu karang dan ekosistem terkait di Kabupaten Kepulauan Selayar. Coremap CTI Pusat Penelitian Oseanografi. Lembaga Ilmu Pengetahuan Indonesia. $115 p$.

Adriman, A. Purbayanto, S. Budiharso, dan A. Damar. 2012. Analisis keberlanjutan pengelolaan ekosistem terumbu karang di kawasan konservasi laut daerah Bintan Timur Kepulauan Riau. J. Perikanan dan Kelautan, 1(17):115.

Angulo, V.J.A. and B.G. Hatcher. 2010. A new typology of benefits derived from marine protected areas. Marine Policy, 34:635-644.

Arifin, T. 2008. Akuntabilitas dan keberlanjutan pengelolaan kawasan terumbu karang di Selat Lembeh, Kota Bitung. Disertasi. Sekolah Pascasarjana Institut Pertanian Bogor. 173hlm.

Bengen, D.G. 2004. Sinopsis ekosistem dan sumberdaya alam pesisir dan lautan. Pusat Kajian Sumberdaya Pesisir dan Lautan. Bogor. 62hlm.

Charles, A.T. 2000. Sustainability fishery system. Sains Mary's University Halifax. Nova Scotia. Canada. 37p.

English, S., C. Wilkinson, and V. Baker. 1994. Survey manual for tropical marine resources. Australian Institute of Marine Science. Townsville. 390p.

Fauzi, A. dan S. Anna. 2005. Pemodelan sumberdaya perikanan dan kelautan untuk analisis kebijakan. Jakarta: Gramedia Pustaka Utama. 343p.

Gomez, E.D. and H.T. Yap. 1988. Monitoring reef condition. In Kenchington RA, Hudson BET, editor. Coral Reef Management Handbook. UNESCO Regional Office for Science and Technology for Sounth East Asia. Jakarta. 171-178pp.

Ilyas, M.S. 2009. Analisis pemanfaatan ruang dalam pengelolaan wilayah pesisir dan pulau-pulau kecil. Studi Kasus: Pulau Pasi, Kabupaten Selayar. Tesis. Sekolah Pascasarjana Universitas Hasanuddin. 104hlm.

International Union on Conservation for Nature [IUCN]. 2004. Managing marine protected areas; a toolkit for the Western Indian ocean. IUCN esastern african regional programme. Nairobi, Kenya. 172p.

Janwar, Z. 2010. Desain zonasi multiguna kawasan konservasi laut daerah Pulau Pasi Kabupaten Kepulauan Selayar Provinsi Sulawesi Selatan. Tesis. Sekolah Pascasarjana Institut Pertanian Bogor. Bogor. 68hlm. 
Kavanagh, P. 2001. Rapid apparaisal of fisheries (RAFFISH) project. University of British Columbia, Fisheries Centre. 34p.

Keputusan Bupati Kepulauan Selayar Nomor: 446. 2011. Tentang penetapan perairan Pulau Pasi dan Perairan Pulau Gusung sebagai kawasan konservasi perairan daerah Kabupaten Kepulauan Selayar. 8hlm.

Kinsman, D.J.J. 1964. Reef coral tolerance of high temperature and salinities. Nature, 202: 1280-1282.

Kuperan, W. 1997. Enforcement and compliance with fisheries regulations in Malaysia, Indonesia, and the Philippines. Research Report. ICLARM, Manila. 25p.

Letser, S.E., B.S. Halpern., L. GrorudCoveret, J. Lubchenco, B.I. Ruttenberg, and S.D. Gaines. 2009. Biologycal effects within no-take marine reserves: a global synthesis. Marine Ecology Progress Series, 384:33-49.

Nikijuluw, V.P.H. 2002. Rezim pengelolaan sumberdaya perikanan. PT. Pustaka Cidesindo. Jakarta. 700hlm.

Nybaken, J.W. 1998. Biologi laut; suatu pendekatan ekologi. Gramedia. Jakarta. 55hlm.

Peraturan Menteri Kelautan dan Perikanan Republik Indonesia Nomor 17. 2008 tentang kawasan konservasi di wilayah pesisir dan pulau-pulau kecil. Jakarta. 23hlm.

Pitcher, T.J. and D. Preikshot. 2001. Rapfish: A rapid appraisal technique to evaluate the sustainabilit ystatus of fisheries. Fisheries Research, 49(3): $255-270$.

Rembet, N.W.J., Unstain, M. Boer, D.G. Bengen, dan A. Fachrudin. 2011. Status keberlanjutan pengelolaan terumbu karang di Pulau Hogow dan Putus-Putus Sulawesi Utara. $J$. Perikanan dan Keluatan Tropis, 3(7):115-122.

Salm, R.V., J.R. Clark, and E. Siirila. 2010. Marine and coastal protected areas: a guide for planners and managemnet. Gland, Swisterland. 396hlm.

Selig, R.E., S.K. Casey, and F.J. Bruno FJ. 2010. Temperature-driven coral decline: the role of marine protected areas Australia. J. Global Change Biology, 18(5):1561-1570.

Susilo, B.S. 2003. Keberlanjutan pembangunan pulau-pulau kecil: Studi kasus kelurahan Pulau Panggang dan Pulau Pari Kepulauan Seribu, DKI Jakarta. Disertasi. Program Pascasarjana Bogor: 233p.
Diterima
: 05 Agustus 2016
Direview :23 Agustus 2016
Disetujui : 23 Maret 2018 